\title{
Preliminary Immunochemical Studies to Detect Lard
}

\author{
Dina Sudjana*1, Lia Amalia ${ }^{2}$, Saepul Adnan ${ }^{3}$ \\ ${ }^{1}$ Halal Center Salman ITB Bandung, Ganesa street No.7, Lb. Siliwangi, Bandung \\ ${ }^{2}$ Universitas Djuanda, Toll Road Ciawi street No. 1, Ciawi, Bogor \\ ${ }^{3}$ Universitas Muhammadiyah Bandung, Soekarno Hatta street No.752, Cipadung Kidul, Bandung \\ e-mail: *ldinasujana@gmail.com
}

*Correspondent Author

DOI: 10.5575/ijhar.v2i1.7819

\begin{abstract}
Detection of lard in food using immunochemical methods has been carried out. This method has been applied and developed in food analysis. The purpose of this study was to detect the presence of lard in food. The method used was immunochemical which in this case is tested to its application in food analysis. The principle method is based on the antigen-antibody reaction, between lipids as antigens that can be deposited by antibodies in the agar medium. Antibodies were obtained by inducing lard into the blood vessels of rabbits. This method is based on the antigen-antibody reaction between fat as an antigen and antibodies that contain anti-lard as reagents and the occurrence of precipitation in agar media. The antibody was obtained by inducing lard, pork broth, and pig plasma into the blood vessels of rabbits. The results of this study were significant.
\end{abstract}

Keywords: antibody, antigen, Immunochemical, lard

\section{Introduction}

Lard is fat of pork that widely used in the food product such as, for commonly used like cooking oil or the same as beef fat or goat fat that used as a flavor compliment in the cooking process, or as butter. The quality of taste and the use of lard itself depend on what part of the fat is taken and how the fat is processed. Lard has a lower saturated fat and cholesterol content compared to butter. Fats in pigs need to go through processing in order to become lard. Lard contains $3770 \mathrm{~kJ}$ of energy per 100 grams. It has boiling point between $86-113^{\circ} \mathrm{C}$ depends on the location of the fat in the body of the pig, the smoke point of $121-218^{\circ} \mathrm{C}$, the iodine value of 71.97, $\mathrm{pH}$ of around 3.4, a saponification value of 255.90, a melting point of 36.8 and a specific gravity of 0.812 (Hilda, 2014).

The utilization of lard in the food industry is often known as "shortening" which is solid fat which has plastic properties with certain stability. It is generally white and often known as white butter. The function of lard includes improving taste, texture, and structure as well as enlarging the volume of cake or bread. Mixing oleo stearin, lard and cottonseed oil which has undergone hydrogenation will form a compound shortening which will produce shortening with a certain consistency that is malleable/plastic at high temperatures and long-lasting. The utilization of lard as additives or processing aids in various food, drug, and cosmetic industries as well as other uses, causes industrial products to be syubhat. Halal MUI, (2014) stated that in the concept of halal haram that halal defines as everything that is permitted by the Shari'ah to be consumed. While haram is everything that prohibited by the Shari'ah to be consumed. Haram food is considered to have more disadvantages or harmful (mudharat) than the good, and if someone still consumes anything haram, he will get sin, except in a forced condition. The Islamic teachings emphasized halal food and haram food as well as drinks. In addition to food safety factors, the halal factor of a food product must also be of concern to the Muslim community (Citrasari, 2013).

These commands and prohibitions are found in the Qur'an surah al-A'raf verse 157 which reads "... and (Allah) justifies for them all that is good and forbids them all that is bad". Even in the hadith of the Prophet (PBUH) narrated by Muslim stated that the halal is clear and the haram is clear; and between the two there are things that are mushabihat (doubtful, vague, unclear, and illegitimate). According to Prof. KH. Ibrahim Hosen as chairman of the MUI fatwa commission (1980-2000) said "If a product has come into contact with technology 
and no longer appears the original form of the material, then the product can be categorized as a shubhat (vague)". For this reason, a halal certification process is needed to ensure the halalness of industrial products. Halal-certified products provide peace, security, and comfort for Muslims in consuming their food.

Government policy to issued halal product guarantee law No. 33 of 2014 is the right step to protect the consumer of Indonesia from non-halal products. Article 4 of the JPH Law states that products that enter, circulate and trade within the territory of Indonesia must be halal-certified. That means that every ingredient either as an additive or processing aids that are entered into food products must be halal and free from illicit ingredients.

Detecting illicit components in ingredients can be carried out through various laboratory searches and analyses. The fatty acid profiling can be done by the physicochemical analysis which includes measurement of specific gravity, refractive index, melting point, iodine number, saponification number. While the quantitative analysis can be done with GCMS, GLC and FTIR (Rohman, 2013). Identification of lard by determining the profile of fatty acids in complex products is very difficult. For this reason, there are some researchers trying to find markers for certain fatty acids that are specifically present in lard. Modern research nowadays is carried out with polymerase chain reaction (PCR), which is one of the molecular biology techniques that are widely used in the study of food authentication. Through DNA analysis, the target of detection is pig DNA. The PCR technique is used for halal authentication purposes because of its ability to detect specific targets on DNA sequences in food products or pharmaceutical products. Further development of conventional PCR technology has been replaced with Realtime - PCR which can be used for qualitative and quantitative analysis (Gatra, 2015).

In addition to developing qualitative and quantitative fatty acid methods, there is a bioanalysis method which involves interactions or bonds between antigens and antibodies. This method is generally used to detect contaminants that have small molecular weight, such as contamination or animal drug residues in food. By increasing the number of contaminants in food products, bioanalysis plays an important role in ensuring food safety. At present, the bioanalysis method is used as an alternative method of chemical instrumentation because it has advantages such as simple workmanship, it does not require intensive sample preparation so that the analysis time is faster, and the analysis cost is cheaper because it does not require instruments or very expensive analytical instruments. Immunoassay or immunochemical analysis is One method of bioanalysis that works based on the specificity of the reaction between antigens and antibodies. Because it has the ability to analyze analytes in low concentrations, this method is very useful for environmental monitoring and food safety analysis (Chen J, 2009). Immunology is a special memory mechanism that specifically recognizes foreign substances (non-self), so contact with various diseases will provide protection (immunity) against the disease. The body's first contact with an organism that causes infection will provide memory to the body to refuse and protect themselves from an organism that causes the same disease or infection.

\section{Materials and Methods}

\subsection{Materials}

The ingredients used including pork, fresh pork blood, lard, beef, chicken, aqua dest, ethanol, sodium hydroxide, oleic acid, dry and dead Mycobacterium tuberculosis, liquid paraffin, agar, sodium bicarbonate, potassium ionide, iodine triclorida, glacial acetic acid, starch, carbon tetra chloride, hydrochloric acid, potassium hydroxide, universal indicator, phenolphthalein, methyl red, potassium dihydrogen phosphate, iodine monochloride, ninhydrin reagents and rabbits as experimental animals. Dropper with volume $5 \mathrm{~mL}, 10 \mathrm{~mL}$; glass funnel; $25 \mathrm{~mL}, 50 \mathrm{~mL}, 100 \mathrm{~mL}$ measuring flask; oven, spatel, analytical balance, vials, glass bottles, measuring cups, petri dishes, autoclaves, syringes, incubators, centrifugations, centrifugation tubes, burettes, erlenmeyer flask, beakers, Bunsen and refrigerators were also used in this research.

\subsection{Preparation of Antigen Raw Materials}

The raw materials used were lard, broth or pork extract and pig plasma. Oil and fat obtained from the heating of animal fats were tested for acid numbers, iodine numbers, and saponification numbers. Pork extract was made from pork by boiling pork in physiological sodium chloride $(\mathrm{NaCl})$ in a concentration of $20 \% \mathrm{w} / \mathrm{v}$ and heated at medium temperature for 
30 minutes. Pig plasma was made by shaking fresh pig blood with Na-EDTA (Sodium Ethylene Diamin Tetra Acetate) 2\%, and then allowed to stand at room temperature for 1 hour, after that the mixture was centrifuged to obtain a supernatant (plasma).

\subsection{Production of Antigen}

The antigen used to induce antibodies is mixed with Freud's complete adjuvant to increase its antigenicity with the ratio of antigen to adjuvant 1: 1 .

\subsection{Experimental animals}

Six white rabbits (Neo hybrid New Zealand) were used, weighing $1.5-2 \mathrm{~kg}$ in normal and healthy conditions and did not experience weight loss during the trial period.

\subsection{Antibody induction}

Animal Experiments are induced by peritoneal and subcutaneous injection of antigens. Injections were carried out four times with the aim to increase the concentration of antibodies obtained. The blood draw is carried out every before and after injection each before and after injection through the marginal veins or the ears of rabbits to test the presence or absence of antibodies.

The first injection was carried out intraperitoneally with a volume of $0.1-0.2 \mathrm{~mL}$, the next injection was carried out in the second and fourth weeks by subcutaneous with a volume of $1 \mathrm{~mL} / 2.5 \mathrm{~kg}$ body weight. The last blood draw was carried out in the seventh week.

\subsection{Testing of Antigen-Antibody Reactions}

Antigen-antibody testing is based on the formation of precipitation. The method used was the Oucterlony method or double immunodiffusion in two dimensions. In this method, an agar medium was used by making wells with a certain pattern.

\section{Results and Discussion}

Analysis of induction of antibody formation, the results of observations of Immunoserum testing and the effect of antigen injection on rabbit body weight are explained as follows:

\subsection{Fat Testing}

Lard, beef tallow oil and chicken oil was made by heating the amount of lard or fat from each of these animals. The oil obtained was then tested for acid numbers, iodine numbers and saponification numbers (Tables 1, $2 \& 3$ ).

Table 1. Comparison of acid numbers between lard, beef tallow oil and chicken oil

\begin{tabular}{cccc}
\hline No & Fat types & Results & References* \\
\hline 1 & Lard & 1,234 & 1,5 \\
2 & Beef tallow & 0,72 & 0,25 \\
3 & Chicken & 1,30 & 1,2 \\
\hline (*): Farmakope Depkes & &
\end{tabular}

Table 2. Comparison of iodine numbers between lard, beef tallow oil and chicken oil

\begin{tabular}{cccc}
\hline No & Fat types & Results & References* \\
\hline 1 & Lard & 57,16 & $56-74$ \\
2 & Beef tallow & 43,14 & $36-44$ \\
3 & Chicken & 68,96 & $66-71,50$ \\
\hline
\end{tabular}

(*): Farmakope Depkes

Table 3. Comparison of saponification numbers between lard, beef tallow oil and chicken oil

\begin{tabular}{cccc}
\hline No & Fat types & Results & References* \\
\hline 1 & Lard & 190,15 & $193-198$ \\
2 & Beef tallow & 196,35 & $196-200$ \\
3 & Chicken & 194,56 & $193-202$ \\
\hline
\end{tabular}

(*): Farmakope Depkes

Based on the data presented above that the range of numbers of acid, iodine and saponification for lard, beef tallow and chicken oil are similar. Therefore, it is difficult to detect the presence of lard with these methods, especially if they are in amounts that are too small. In addition, the processing, purity of livestock, age of livestock, and storage methods also determine the amount of lard content obtained.

\subsection{Analysis of Induction of Antibody Formation}

The six rabbits were divided into three groups; each group was induced with pig plasma, pork broth and pork lard oil. Antibody induction was carried out four times. The blood draw is carried out every before and after injection each before and after injection. A complete Freud adjunctive mixture injection was carried out on the third induction. Schedule of administration intervals and antigen concentrations used are presented in Table 4. 
Table 4. Schedule of Antigen delivery to experimental rabbit

\begin{tabular}{|c|c|c|c|c|c|c|c|c|c|}
\hline \multirow[t]{2}{*}{ Week } & \multicolumn{3}{|c|}{ Plasma } & \multicolumn{3}{|c|}{ Broth } & \multicolumn{3}{|c|}{ Oil } \\
\hline & $\mathrm{V}$ & $\mathrm{R}$ & $\mathrm{C}$ & V & $\mathrm{R}$ & $\mathrm{C}$ & V & $\mathrm{R}$ & $\mathrm{C}$ \\
\hline $\mathrm{I}$ & 0,2 & I.P & 25 & 0,2 & IP & 20 & 0,2 & IP & 50 \\
\hline II & 1 & S.C & 10 & 1 & S.C & 10 & 1 & S.C & 50 \\
\hline III & \multicolumn{3}{|c|}{ No injection was performed } & \multicolumn{3}{|c|}{ No injection was performed } & \multicolumn{3}{|c|}{ No injection was performed } \\
\hline IV & 1 & S.C & 50 & 1 & S.C & 10 & 1 & S.C & 50 \\
\hline $\mathrm{V}$ & 1 & I.P & 100 & 1 & I.P & 20 & 1 & I.P & 100 \\
\hline VI & \multirow{2}{*}{\multicolumn{3}{|c|}{ No injection was performed }} & \multicolumn{3}{|c|}{ No injection was performed } & \multicolumn{3}{|c|}{ No injection was performed } \\
\hline VII & & & & \multicolumn{3}{|c|}{ Blood Collection } & \multicolumn{3}{|c|}{ Blood Collection } \\
\hline
\end{tabular}

V: Volume of injection; R: Route; C: Concentrations; S.C: Subcutaneous; I.P: Intraperitoneal

\subsection{Effect of Antigen Injection on Rabbit Body Weights}

The results showed that not all of the experimental groups were able to produce the same antibodies. This is due to the fact that there are genetic variations among experimental animals, even though age, body weight, and sex are treated as homogeneously as possible. The complete Freud adjunctive addition resulted in a decrease in the bodyweight of rabbits caused by the bacterium tuberculosis began to work in the body of the rabbit so that it has a fever that causes a decrease in appetite so it impacts on weight loss. There is data rabbit body weights before, during and after the experiment (Table $5)$.

Table 5. Data of Ouchterlony double immunodiffusion

\begin{tabular}{|c|c|c|c|c|c|c|c|c|c|}
\hline $\begin{array}{c}\text { Rabbit } \\
\text { Number }\end{array}$ & $\begin{array}{c}\text { Serum } \\
\text { collection }\end{array}$ & PP & PB & PL & PP' & PB' & PL' & MA & MS \\
\hline R-PP 1 & \multirow{6}{*}{ I } & - & - & - & - & - & - & - & - \\
\hline R-PP 2 & & - & - & - & - & - & - & - & - \\
\hline R-PB 1 & & - & - & - & - & - & - & - & - \\
\hline R-PB 2 & & - & - & - & - & - & - & - & - \\
\hline R-PL 1 & & - & - & - & - & - & - & - & - \\
\hline R-PL 2 & & - & - & - & - & - & - & - & - \\
\hline R-PP 1 & \multirow{6}{*}{ II } & - & - & - & - & - & - & - & - \\
\hline R-PP 2 & & - & - & - & - & - & - & - & - \\
\hline R-PB 1 & & - & - & - & - & - & - & - & - \\
\hline R-PB 2 & & - & - & - & - & - & - & - & - \\
\hline R-PL 1 & & - & - & - & - & - & - & - & - \\
\hline \multirow[t]{2}{*}{ R-PL 2} & & - & - & - & - & - & - & - & - \\
\hline & III & \multicolumn{8}{|c|}{ REST } \\
\hline R-PP 1 & \multirow{6}{*}{ IV } & + & + & + & - & - & + & - & - \\
\hline R-PP 2 & & + & + & + & - & - & + & - & - \\
\hline R-PB 1 & & + & + & + & - & - & - & - & - \\
\hline R-PB 2 & & + & + & + & - & - & - & - & - \\
\hline R-PL 1 & & + & - & - & - & - & - & - & - \\
\hline R-PL 2 & & + & - & - & - & - & - & - & - \\
\hline R-PP 1 & \multirow{6}{*}{ V } & + & + & + & - & - & - & - & - \\
\hline R-PP 2 & & + & + & - & - & - & - & - & - \\
\hline R-PB 1 & & + & + & - & - & - & - & - & - \\
\hline R-PB 2 & & + & - & + & - & - & - & - & - \\
\hline R-PL 1 & & + & - & + & - & - & - & - & - \\
\hline R-PL 2 & & + & - & + & - & - & - & - & - \\
\hline
\end{tabular}

Note: R-PP: Rabbits induced by pig plasma; R-PB: Rabbits induced by pork broth; R-PL: Rabbits induced by pork lard oil; PP: pig plasma; PB: pork broth; PL: pork lards oil; PP': Plasma with complete Freud adjunctive; PB': Broth complete Freud adjunctive; PL': Pork lard oil complete Freud adjunctive; MA: Chicken Oil; MS: Lard; + : Precipitation lines form; - : No Precipitation lines form. 
Table 6. Effects of Antigen Injection on Rabbit Body Weight

\begin{tabular}{cccccccc}
\hline \multirow{2}{*}{ Rabbit } & \multirow{2}{*}{$\begin{array}{c}\text { Age } \\
\text { (month) }\end{array}$} & Types & \multicolumn{5}{c}{ Body weight (Kg) } \\
\cline { 4 - 8 } & & I & II & III & IV & V \\
\hline 1 & 4 & 0 & 2,4 & 2,7 & 2,9 & 2,9 & 2,5 \\
2 & 4 & 0 & 2,1 & 2,5 & 2,9 & 2,5 & 2,3 \\
3 & 4 & 0 & 2,3 & 2,7 & 2,8 & 2,6 & 2,8 \\
4 & 4 & 0 & 2,5 & 2,6 & 2,6 & 2,4 & 1,8 \\
5 & 5 & 0 & 3,1 & 3,1 & 3,2 & 3,0 & 3,0 \\
6 & 5 & 0 & 3,2 & 3,0 & 3,0 & 3,0 & 3,0 \\
\hline
\end{tabular}

\section{Conclusion}

The development of immunochemical testing techniques has led to applications, not only in the field of clinical diagnosis but also for determining the exposure of a compound to a substance. The use of plasma and pork broth aimed to increase the molecular weight of antigens, in order to be able to induce antibodies anti-lard. The immunochemical method used is quite yielding because it has a high specificity and a high level of sensitivity. Increasing the antigenicity of the lard may be needed. The use of immunochemical as an alternative in detecting lard is quite specific from the absence of cross reactions from antigens. in the case of immunochemical analysis of Lard, further research is needed to find ways to improve the immune response, increase the number of antibodies as well as maximize the result of the lard detection. Further research is needed to maximize the manufacture for better handling of antigens as they are very easily influenced by environmental factors. Further research also needs to be done to improve the evaluation of antibody-antigen reactions with a higher level of accuracies such as using the ELISA (Enzyme-Linked Immuno Assay) and RIA (radioimmunoassay) methods.

\section{References}

Allen J. C. \& C. J Smith. (1987). Enzyme Linked Imunoassay Kit for Routine Food Analysis. Tibtec, 5.

Chen J. X. F. (2009). A Novel Quantum DotBased Fluoroimmunoassay Method for Detection Of ENR Residue in Chicken. Food Chemistry.

Citrasari, D. 2015. Penentuan Adulterasi Daging Babi Pada Pada Nugget AyamMenggunakan NIR dan Kemometrik. Skripsi. Fakultasi Farmasi. Universitas Jember.
Djatmiko, B \& Wijaya, A. P. (1974). Minyak dan Lemak Department Teknologi Hasil Pertanian. Fateta. IPB.

Ditjen POM, Depskes RI., 1979. Farmakope Indonesia ed 3, Depkes RI, Jakarta.

Halal MUI. http://www.halalmui.org/newMUI/ diakses pada 20 Februari 2014.

Hiilditch T. P. (1979). Chemical Contituen of Natural Fats, $2^{\text {nd }}$ ed. Chapman and Hill Ltd: London.

Hilda, L. (2014), Analisis Kandungan Lemak Babi dalam Produk Pangan di Padang Sidimpuan Secara Kualitatif dengan Menggunakan Gas Kromatografi. Tesis. Padang Sidimpuan.

Garvey, J. S. (1977). Metode in Imunologi, 3rd, ed Addison. Weshley publ Co. Inc.

Gatra. (2015). Melindungi Umat melalui Penelitian. Gatra Edisi Lebaran (Bisnis Halal Gaya Hidup Halal).

Kabat, E. A. (1976). Structure Concept In Imunology And Immunochemestry, New York, Chicago.

Kimbal, J. W. (1978). Introduction to Imunology $2^{\text {nd }} e d$. New York: Macmillan publ Co.

Kataren, S. (1986). Minyak dan Lemak Pangan. Jakarta: UI press.

Kisman, S. (1989). Kimia Analisis Bahan Makanan. Program Study Teknologi Pangan UNPAS.

Meyer, L. H. (1979). Fat and Other Lipidin Food Chemistry. Berlin: Springer.

Nowothy, A. (1979). Basic Exersises in Imunochemistry a Laboratorium. Berlin.

Rohman, A. (2013). Analisis Komponen Makanan. Yogyakarta: Graha Ilmu.

Warr, G. (1984). Antibody as a Tool. New York: John Willey and Son. 